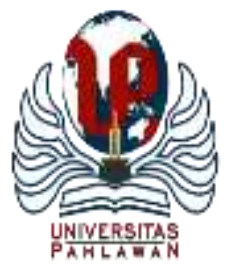

Edukatif : Jurnal Ilmu Pendidikan Volume 4 Nomor 1 Tahun 2022 Halm 516 - 523

EDUKATIF: JURNAL ILMU PENDIDIKAN

Research \& Learning in Education

https://edukatif.org/index.php/edukatif/index

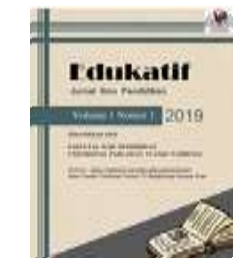

\title{
Pengembangan Media Pop-Up Book terhadap Keterampilan Berpikir Kritis pada Siswa Sekolah Dasar
}

\author{
Lailatus Suroiha $^{1 凶}$, Galuh Kartika Dewi ${ }^{2}$, Satrio Wibowo ${ }^{3}$ \\ Pendidikan Guru Sekolah Dasar, STKIP PGRI Sidoarjo, Indonesia ${ }^{1,2,3}$ \\ E-mail : ichacoe49@gmail.com¹ ${ }^{1}$, galuhkartika86@ gmail.com ${ }^{2}$, sejarahsatrio@ gmail.com ${ }^{3}$
}

\begin{abstract}
Abstrak
Peneliti memiliki tujuan pada pelaksanaan penelitian ini, yaitu menghasilkan media pop-up book untuk melatih keterampilan berpikir kritis kelas V Sekolah Dasar. Dalam penelitian ini, peneliti menggunakan jenis penelitian research and development. Peneliti berupaya mengembangkan pop-up book sebagai referensi penelitian untuk mengetahui keterampilan berpikir kritis siswa sebelum dan sesudah menggunakan media pembelajaran. Hasil dari penelitian ini memperoleh nilai $83 \%$ dari ahli media, hal ini berarti media layak digunakan oleh siswa. Dari ahli materi sebanyak $88 \%$ dengan kriteria sangat layak digunakan, untuk ahli pembelajaran sebanyak $88 \%$ dan 93\% dengan kategori sangat layak digunakan. Keterampilan berpikir kritis siswa mendapat skor 91\% dengan kriteria sangat layak diuji cobakan.
\end{abstract}

Kata Kunci: Media Pembelajaran, Pop-Up Book, Keterampilan Berpikir Kritis.

Abstract

The researcher has a goal in carrying out this research, namely to produce a pop-up book media to train critical thinking skills for fifth grade elementary school. In this study, the researcher used the type of research and development research. Researchers are trying to develop a pop-up book as a research reference to determine students' critical thinking skills before and after using learning media. The results of this study obtained a score of $83 \%$ from media experts, this means that the media is very suitable for use by students. From material experts as much as $88 \%$ with very suitable criteria for use, for learning experts as much as $88 \%$ and $93 \%$ with very suitable categories for use. Student's critical thinking skills got a score $91 \%$ with criteria very worthy of being tested.

Keywords: Learning Media, Pop-Up Book, Critical Thinking Skills

Copyright (c) 2022 Lailatus Suroiha, Galuh Kartika Dewi, Satrio Wibowo

$\triangle$ Corresponding author

Email : ichacoe49@gmail.com

DOI $\quad$ : https://doi.org/10.31004/edukatif.v4i1.1856

ISSN 2656-8063 (Media Cetak)

ISSN 2656-8071 (Media Online) 
517 Pengembangan Media Pop-Up Book terhadap Keterampilan Berpikir Kritis pada Siswa Sekolah Dasar - Lailatus Suroiha, Galuh Kartika Dewi, Satrio Wibowo

DOI: https://doi.org/10.31004/edukatif.v4i1.1856

\section{PENDAHULUAN}

Pendidikan merupakan muatan utama perkembangan kehidupan manusia. Pendidikan dapat diartikan sebagai pintu untuk mengenali serta memahami segala aspek perkembangan manusia. Di Indonesia, kebijakan pembelajaran yang diumumkan oleh Pemerintah Republik Indonesia bersifat wajib selama 12 tahun. Pendidikan dimulai sejak Sekolah Dasar hingga Perguruan Tinggi.

Pendidikan tingkat formal pertama yang merupakan bagian dari rangkaian pendidikan di Indonesia adalah sekolah dasar. Oleh karena itu peran pendidik atau guru di sekolah dasar adalah membawa pengetahuan sebanyak-banyaknya ke dunia ini dalam lingkungan kegiatan anak, baik secara internal maupun eksternal sebagai pengalaman belajar. Salah satu cara pendidik yang dapat mendukung proses belajar anakanak secara alami yaitu dengan menyediakan media pembelajaran yang kreatif dan inovatif untuk merangsang minat belajar serta menumbuhkan kemampuan berpikir kritis anak. Siswa harus berani menerima tantangan untuk mencoba hal-hal baru. Berani mencoba berarti menerima dan menganalisis masalah, serta menemukan solusi dari masalah tersebut. Proses pembelajaran membutuhkan keterampilan berpikir kritis untuk mencapai pembelajaran yang efektif.

Rachmantika (2019) berpendapat bahwa berpikir kritis membutuhkan upaya untuk menguji setiap hipotesis berdasarkan bukti dan kesimpulan yang telah diambil. Sementara itu, Ennis (2015) menambahkan definisi umum komponen tujuan berpikir kritis, yaitu, "Reasonable reflective thinking focused on deciding what to believe or do." Dapat diartikan bahwa, berpikir kritis haruslah masuk akal dan berdasarkan logika, pemikiran instropektif akan berpusat pada pengambilan keputusan apa yang harus dipercaya dan apa yang harus dilakukan.

Berpikir kritis adalah metode berpikir yang mempunyai sasaran untuk menerima reaksi pembaca dari penulis sebagai bentuk kemampuan berpikir secara logis dan sistematis (Sulistiani \& Masrukan, 2017). Dalam hal ini berpikir logis sistematis di dalam kelas berarti harus ada keterkaitan antara hasil dari proses pembelajaran. Siswa adalah subjek yang dapat berubah menjadi lebih baik dan berproses secara alami. Salah satu pembelajaran yang dapat menyediakan kegiatan dalam meningkatkan keterampilan berpikir kritis dengan menonjolkan suatu masalah, dapat menggunakan media pembelajaran pop-up book sebagai acuan dalam pembuatan media belajar yang menarik.

Guru dan orang tua harus mampu untuk menganalisis asumsi serta pendapat tentang informasi yang benar. Demikian pula untuk siswa diajarkan informasi yang logis dan menarik, supaya lebih memahami informasi apa yang dianggap benar. Metode dan media yang efektif mampu mengembangkan pemikiran siswa agar dapat menarik perhatian anak dan mendorong mereka untuk berpikir kritis.

Berdasarkan hasil observasi pada siswa MI Darul Hikmah kelas V, peneliti mengamati bahwa kurangnya minat belajar siswa saat pembelajaran di kelas, karena metode pembelajaran yang di lebih menekankan pada metode ceramah, serta kurangnya media pembelajaran dalam mengajar, guru masih menggunakan media papan tulis. Akibatnya, lingkungan belajar di kelas menjadi monoton, dan siswa tidak lagi tertarik untuk belajar. Alasan khusus dari rendahnya tingkat aktivitas dan pemikiran siswa adalah kegiatan belajar dalam kelas cenderung hanya mengerjakan LKS (Lembar Kerja Siswa). Akibat tersebut berdampak pada banyaknya siswa yang masih stagnan atau pasif, kurang berminat untuk belajar, sehingga umpan balik dari setiap pembelajaran di kelas menjadi kurang. Dari pegamatan tersebut, peneliti merasa membutuhkan suatu media yang dapat menunjukkan keaktifan siswa selama proses pembelajaran. Sehingga keterampilan berpikir kritis siswa tersebut mengalami peningkatan.

Penelitian pendahuluan dilakukan melalui observasi kelas dan wawancara dengan guru. Penelitian dilakukan terhadap siswa kelas $\mathrm{V}$ yang memiliki $\mathrm{KKM} \geq 70$, dengan rata-rata nilai sebesar 78,3. Pada kelas ini, terdapat juga siswa yang tidak memenuhi standar KKM. Contohnya saja: penelitian dari 25 siswa, dengan nilai kriteria ketuntasan minimal(KKM) $\geq 70$ atau $40 \%$ dari 25 siswa yaitu 10 siswa, sedangkan $60 \%$ atau 15 
siswa dengan nilai kriteria ketuntasan minimum $(\mathrm{KKM})<70$. Oleh karena itu, kurangnya pemahaman siswa selama pembelajaran dapat diartikan sebagai melambatnya keterampilan berpikir siswa karena pembelajaran yang kurang menarik.

Dari pengamatan tersebut, metode pembelajaran dinilai kurang efektif, serta memerlukan pengembangan media pembelajaran yang menarik, pembelajaran yang kurang menarik membuat siswa malas dalam belajar, sehingga siswa kurang merangsang cara berpikirnya. Salah satu cara meningkatkan semangat dan motivasi belajar pada anak yaitu dengan menggunakan media pembelajaan yang menarik. Dengan termotivasinya anak menggunakan media saat pembelajaran, secara otomatis siswa dapat merangsang pemikiran yang kritis dan logis. Media tersebut adalah media pop-up book.

Dewanti (2019) mengartikan bahwa pop-up book merupakan buku yang memiliki potensi adanya gerakan, serta interaksi dengan menggunakan kertas sebagai bahan pokok untuk membuat lepitan, lilitan, bentuk roda, ataupun berbentuk putaran. Definisi lain pop-up book adalah buku dengan bagian yang bergerak dan mengandung elemen 3 dimensi. Sejalan dengan makna tersebut, media pop-up book juga dapat menampilkan gambar dengan efek emboss (timbul) yang dapat menarik minat siswa dalam belajar. Halaman pop-up book juga dapat disesuaikan dengan materi pembelajaran pilihan dan dirancang sesuai dengan kreativitas guru. Media pop-up book juga dapat merangsang imajinasi anak dan menambah pengetahuananak. Hal ini mengetahui cara menjelaskan bentuk suatu benda, menambah kosa kata, memahami keterampilan anak, dan meningkatkan daya pikir kritis anak. Media pop-up book menjadi media pembelajaran yang luar biasa dan beragam.

Manfaat dari media pop-up book, yaitu: a) menumbuhkan kecintaan anak-anak pada buku dan membaca; (b) bermanfaat untuk mengembangkan keterampilan berpikir kritis serta memupuk kreativitas, c) gambar dan bentuk yang menarik untuk merangsang minat serta memberi mendorongan dalam memahami bacaan (Dewanti et al., 2019). Menurut Aeni (2018), pemanfaatan media pop-up book dalam pembelajaran di kelas ialah meningkatkan kemampuan berpikir kritis siswa. Pernyataan tersebut sesuai dengan hasil penelitian Lestari (2020) yang menunjukkan bahwa pop-up book mempunyai hasil yang relevan terhadap kemampuan berpikir kritis siswa. Dari uraian tersebut, peneliti menyimpulkan bahwa media pop-up book memiliki keunggulan yang berhubungan dengan keterampilan berpikir kritis siswa.

Berdasarkan informasi diatas, disimpulkan bahwa media pop-up book sangat relevan terhadap keterampilan berpikir kritis. Proses pembelajaran yang diterapkan melalui pengunaan media pop-up book dapat mendorong siswa belajar dengan minat yang tinggi, sehingga secara tidak langsung akan meningkatkan keterampilan berpikir kritis siswa. Dengan kata lain, aktivitas yang diciptakan oleh guru dalam kegiatan pembelajaran dengan bantuan media pop-up book mempengaruhi proses pengembangan berpikir kritis siswa. Hal ini dikarenakan proses pembelajaran yang menyenangkan dan membantu siswa mengeksplorasi diri dalam menghadapi masalah yang akan dihadapinya. Permasalahan yang dimaksud adalah siswa dapat meyelesaikan soal-soal yang diberikan guru dan menjawab dengan benar sesuai dengan apa yang ada di pikirannya.

Berlandaskan penjelasan dari latar belakang, peneliti tertarik untuk melakukan penelitian yang berjudul "Pengembangan Media Pop-Up Book Untuk Meningkatkan Keterampilan Berpikir Kritis Pada Siswa Kelas V Sekolah Dasar". Pada penelitian ini siswa tidak hanya melihat dan merasakan media pop-up book, tetapi juga dilibatkan dalam pengerjaan soal-soal yang terdapat pada media tersebut. Perbedaan penggunaan media dengan penelitian terdahulu adalah, jika pada penelitian yang sudah dilakukan siswa hanya memahami pelajaran melalui media dengan satu materi pelajaran yang sudah disiapkan, maka dalam penelitian ini peneliti menambahkan materi dan soal sesuai dengan pelaksanaan kurikulum 2013 dengan pembelajaran berbasis inkuiri menggunakan buku Tema 4 Subtema 1 pada kelas V Sekolah Dasar. 
519 Pengembangan Media Pop-Up Book terhadap Keterampilan Berpikir Kritis pada Siswa Sekolah Dasar - Lailatus Suroiha, Galuh Kartika Dewi, Satrio Wibowo

DOI: https://doi.org/10.31004/edukatif.v4i1.1856

\section{METODE PENELITIAN}

Jenis penelitian ini adalah research and development. Peneliti mencoba mengembangkan salah satu produk berupa media belajar pop-up book dan peneliti menguji media tersebut pada siswa kelas V Sekolah Dasar. Pelaksanaan penelitian bertempat di MI Darul Hikmah Prasung, Kecamatan Buduran, Kabupaten Sidoarjo, Jawa Timur, pada tahun ajaran semester ganjil 2021/2022. Populasi penelitian adalah siswa kelas V, MI Darul Hikmah Prasung, dengan 30 sampel penelitian. Teknik penelitian ini dalam pengambilan sampel adalah random sampling. Desain penelitian menggunakan model pengembangan Borg and Gall, langkahlangkahnya sebagai berikut ini:

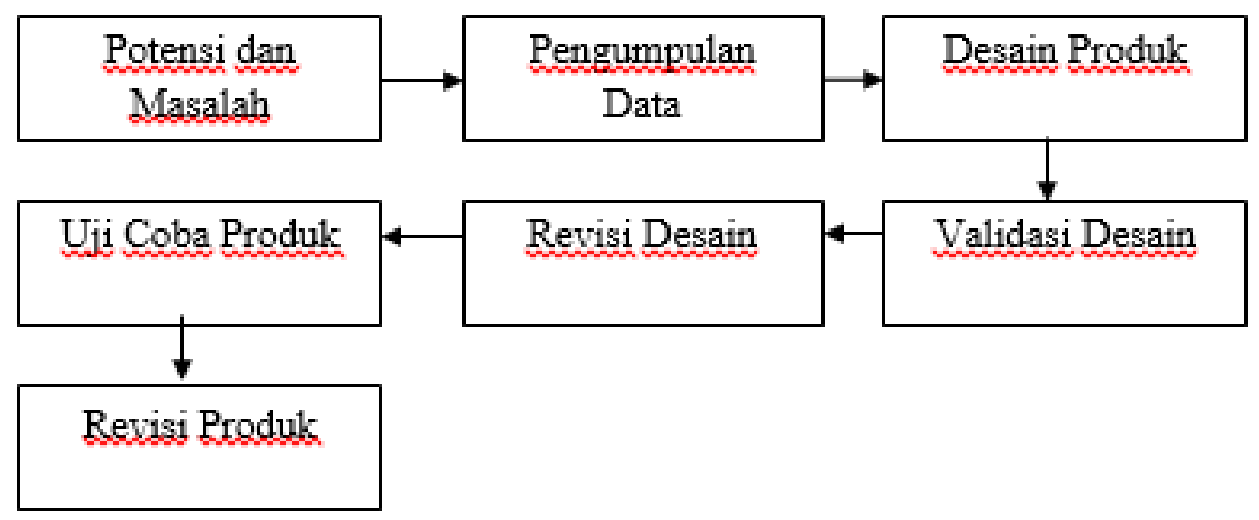

(Sugiyono, 2016)

\section{Gambar 1 Desain Penelitian}

Pada penelitian ini digunakan intrumen berupa lembar observasi, lembar validasi media belajar, dan lembar acuan keterampilan berpikir kritis siswa. Pengumpulan data penelitian menggunakan teknik observasi yang bertujuan untuk mengetahui adanya kemampuan berpikir kritis siswa sebelum dan sesudah menggunakan media pop-up book, dan dokumentasi dengan tujuan untuk memperoleh catatan peristiwa saat penelitian berlangsung. Sedangkan, pada penganalisisan data, peneliti menggunakan beberapa angket, yaitu: 1) angket kebutuhan pengembangan media pop-up book yang diolah menggunakan data deskriptif kualitatif sesuai data asli penelitian, 2) angket validitas media pop-up book, 3) angket tanggapan guru dan respon siswa, 4) angket keterampilan berpikir kritis siswa. Data yang sudah didapatkan dari angket akan diolah secara kuantitatif menggunakan skala likert dengan rumus:

$$
\text { Nilai Persentase }=\frac{\text { Jumlah seluruh skor }}{\text { skor terting gi } x \text { jumlah soal }} \times 100 \%
$$

\section{Gambar 2 Rumus Persentase}

Peneliti melakukan analisis deskriptif kualitatif setelah melakukan uji analisis deskriptif kuantitatif, hal ini bertujuan untuk mengolah data dari validasi ahli dan hasil angket respon guru dan siswa. Teknik ini dilakukan dengan mengorganisasikan informasi dari data kualitatif yang berbentuk saran perbaikan media yang terdapat dalam hasil penelitian. Analisis data berfungsi sebagai pedoman untu merevisi pengembangan produk media pembelajarn pop-up book. 
DOI: https://doi.org/10.31004/edukatif.v4i1.1856

\section{HASIL DAN PEMBAHASAN PENELITIAN}

\section{HASIL}

Hasil dari penelitian berbentuk pengembangan ini menghasilkan suatu produk media yang menjelaskan tentang "Peredaran Darahku Sehat" yang terdapat pada Tema 4 Subtema 1 Kelas V Sekolah Dasar. Produk media yang sudah selesai serta sesuai dengan yang dikembangkan, akan dilakukan validasi oleh ahli materi, ahli media, dan ahli pembelajaran.

Langkah awal, yang dapat dilakukan adalah menyiapkan media pop-up book. Pada tahap ini peneliti menjelaskan identifikasi masalah dan potensi siswa, tujuan pembelajaran yang dilakukan, serta karakteristik dari siswa kelas V Sekolah Dasar. Analisis pembelajaran yang diperlukan untuk pengembangan produk adalah sebagai berikut:

\section{Pengumpulan Data}

Pada tahap ini, identifikasi tujuan umum dari pembelajaran dengan melakukan penilaian kebutuhan dan menentukan tujuan. Langkah ini dimaksudkan untuk menentukan apa yang ingin dilakukan siswa setelah menghadiri pembelajaran Tema 4 Subtema 1 . Tujuan umum, merupakan pernyataan yang menggambarkan keterampilan yang perlu dimiliki siswa setelah menghadiri pembelajaran. tujuan umum ditetapkan berdasarkan hasil dari analisis kebutuhan siswa, RPP, serta masukan dari ahli materi dan ahli media.

Tahap pertama peneliti akan menjelaskan keterampilan berpikir kritis yang harus dimiliki siswa setelah menggunakan media pop-up book berdasarkan buku Tema 4 Subtema 1 kelas V SD. Penyajian tersebut didasarkan pada kompetensi ini dan indikator yang akan dicapai selama pembelajaran berlangsung. Beberapa sekolah dasar dalam proses pembelajaran kurikulum 2013 yang menekankan pada pembelajaran berbasis inkuiri memiliki masalah yang sama, yakni keterbatasan media belajar. Karena itu, peneliti mengembangkan media pop-up book pada Tema 4 Subtema 1, yang diharapkan dapat membantu peran guru dalam memberikan materi pelajaran kepada siswa, sehingga penyampaian materi lebih bervariasi.

\section{Desain}

Setelah analisis materi, tujuan pembelajaran, dan karakteristik siswa, langkah selanjutnya adalah merancang media. Langkah-langkah tersebut adalah: menyiapkan serta menyediakan alat dan bahan yang digunakan dalam membuat pop-up book, membuat rancangan pop-up book, serta membuat produk pop-up book untuk kelas V Tema 4 Subtema 1.

\section{Validasi Desain}

Apabila produk pertama selesai dibuat, tahapan selanjutnya adalah menvalidasi desain. Pada tahap validasi ini, produk yang dikembangkan divalidasi oleh ahli materi, ahli media, serta ahli pembelajaran untuk menerima masukan, saran, dan umpan balik atau revisi atas penyempurnaan produk. Setelah diverivikasi oleh ahli materi pada media, skornya adalah $85 \%$ dan skor tertinggi adalah 4 , yang dinyatakan sangat layak digunakan. Validasi media oleh ahli media berjumlah $83 \%$ dengan nilai tertinggi 3, ini berarti bahwa media tersebut sangat layak digunakan, meskipun terdapat beberapa revisi desain pada bagian tertentu.

Sedangkan validasi oleh ahli pembelajaran, yaitu respon tanggapan dari siswa dan guru, produk memperoleh masing-masing nilai $88 \%$ dari angket respon guru, sedangakan pada angket respon siswa mendapat 93\% dengan skor tertinggi adalah 4. Produk tersebut dinyatakan sangat layak digunakan oleh siswa berdasarkan validasi oleh wali kelas dan siswa kelas V Sekolah Dasar.

\section{Uji Coba Produk}

Langkah selanjutnya adalah pengujian produk kepada siswa kelas V. Setalah produk diterapkan pada siswa, dapat diketahui bahwa keterampilan berpikir kritis siswa kelas $\mathrm{V}$, dapat mengalami peningkatan setelah menggunakan media pop-up book dengan persentase sebanyak $91 \%$, ini dapat diartikan bahwa media pop-up 
521 Pengembangan Media Pop-Up Book terhadap Keterampilan Berpikir Kritis pada Siswa Sekolah Dasar - Lailatus Suroiha, Galuh Kartika Dewi, Satrio Wibowo

DOI: https://doi.org/10.31004/edukatif.v4i1.1856

book berhasil meningkatkan keterampilan berpikir kritis siswa kelas V MI Darul Hikmah Prasung. Hasil penelitian yang dijabarkan dapat terlihat dari tabel berikut ini.

Tabel 1

Hasil Persentase Uji Kelayakan Media Melalui Angket Validitas

\begin{tabular}{ccccc}
\hline Validasi Angket & $\begin{array}{c}\text { Skor } \\
\text { tertinggi }\end{array}$ & $\begin{array}{c}\text { Jumlah } \\
\text { seluruh skor }\end{array}$ & Persentase (\%) & Kategori \\
\hline Ahli materi & 4 & 55 & $85 \%$ & Sangat layak \\
\hline Ahli media & 3 & 35 & $83 \%$ & Sangat layak \\
\hline $\begin{array}{c}\text { Respon guru } \\
\text { terhadap media }\end{array}$ & 4 & 46 & $88 \%$ & Sangat layak \\
\hline $\begin{array}{c}\text { Respon siswa } \\
\text { terhadap media }\end{array}$ & 44 & 1167 & $93 \%$ & Sangat layak \\
\hline $\begin{array}{c}\text { Keterampilan } \\
\text { berpikir kritis }\end{array}$ & 4 & 22 & $91 \%$ & Sangat layak \\
\hline
\end{tabular}

\section{PEMBAHASAN}

Pengembangan media pop-up book pada pembelajaran Tema 4 Subtema 1 kelas V Sekolah Dasar dilakukan dengan model Borg and Gall. Model ini merupakan model pengembangan dimana penemuan dan hasil penelitiannya digunakan untuk mempersiapkan rancangan pembelajaran, yang selanjutnya akan diujikan kepada siswa (Sugiyono, 2016). Alasan peneliti menggunakan model penelitian ini adalah, model tersebut lebih mudah untuk digunakan dalam pengembangan media belajar dan proses revisi produk.

Dari hasil yang telah dijabarkan, pengembangan media pop-up book pada Tema 4 Subtema 1 kelas V Sekolah Dasar menunjukkan hasil secara keseluruhan adalah $\geq 61 \%$, dengan persentase tersebut media pop-up book memenuhi kriteria kelayakan penggunaan media untuk Sekolah Dasar, khususnya pada kelas 5 dengan Tema 4 Subtema 1. Banyak siswa yang merasa lebih memahami materi pelajaran setelah menggunakan media tersebut. Para siswa lebih tertarik dengan media yang baru mereka lihat. Mereka memiliki antusiasme yang tinggi terhadap media pembelajaran yang unik dan menarik. Hal ini terlihat dari data hasil angket keterampilan berpikir kritis siswa yang memiliki nilai persetanse sebanyak $91 \%$ dan menunjukkan kategori media pop-up book mampu meningkatkan keterampilan berpikir kritis siswa. Para siswa yang mempunyai nilai lebih rendah dari KKM akan terbantu melalui penggunaan media ini dalam memahami materi pelajaran dan mengerjakan soal. Hal ini sesuai dengan penelitian yang dilakukan oleh Malfia Arip (Arip \& Aswat, 2021) tentang media pop-up book untuk meningkatkan hasil belajar siswa yang memperoleh hasil penelitian dengan kriteria persentase sebanyak $86,1 \%$ pada siklus kedua, menunjukkan kategori bahwa media pop-up book berhasil dalam meningkatkan hasil belajar siswa pada mata pelajaran IPA.

Guru-guru juga banyak terbantu dalam menyampaikan materi pelajaran kepada siswa. Siswa menjadi lebih bersemangat dalam belajar serta mampu memahami pelajaran dengan baik. Baik respon guru dan respon siswa memiliki hasil yang baik dalam menggunakan media pop-up book. Didasarkan pada hasil angket ahli pembelajaran yang memiliki persentase dengan kategori layak digunakan di lingkungan sekolah dasar. Peneliti mendapatkan saran dari ahli pembelajaran untuk memperbanyak materi dalam media yang digunakan oleh siswa. Selain mendapat masukan dari wali kelas V, peneliti juga mendapatkan tanggapan yang bagus dari siswa, banyak dari mereka terbantu dengan adanya media pembelajaran.

Ahli materi memberikan saran bahwa sebuah produk atau media perlu adanya keterkaitan antara materi dan media. Selain itu, suatu media harus mempunyai petunjuk penggunaan yang jelas, supaya penggunaannya dapat dimaksimalkan. Pada validasi media oleh ahli media mempunyai nilai $83 \%$ berarti produk sangat layak digunakan. Angka persentase ini diperoleh karena media pop-up book yang terdapat banyak gambar dari pada materi akan membingungkan siswa dalam proses belajaranya. Siswa akan lebih banyak melihat dan 
memainkan gambar dibandingkan memahami materi pelajaran. Media pop-up book juga dianjurkan memiliki judul yang menarik, khususnya judul yang memberi ajakan untuk dilakukan oleh siswa. Untuk ahli pembelajaran tidak ada saran yang khusus karena media tersebut sangat layak digunakan dalam proses pembelajaran sehari-hari. Dari saran dari beberapa ahli tersebut, peneliti dapat mengembangkan media pop-up book yang lebih baik untuk kedepannya khususnya pada pembelajaran Tema 4 Subtema 1 kelas V Sekolah Dasar.

\section{KESIMPULAN}

Pada penelitian pengembangan ini menghasilkan suatu produk media pembelajaran berbentuk pop-up book yang dibuat menggunakan prosedur model Borg and Gall. Seusai menggunakan media pop-up book, siswa mengalami peningkatan pada pemahaman materi pelajaran. Faktor utama yang mempengaruhi adalah, siswa tersebut memahami materi pelajaran dengan media yang menarik, berwarna, bisa disentuh, serta bervariasi bentuknya. Hal ini mempengaruhi pemahaman siswa terhadap materi pelajaran yang disampaikan oleh guru. Dari data tersebut, disimpulkan bahwa media pop-up book dapat merangsang kemampuan berpikir kritis siswa. Pembelajaran dengan media pembelajaran dinilai lebih efektif dibandingkan pembelajaran konvesional yang monoton. Siswa menjadi kian tertarik dalam memulai pembelajaran dan lebih mudah memahami materi pelajaran. Dengan media pembelajaran, siswa akan lebih aktif, kreatif, dan inovatif dalam belajar. Saran dari peneliti untuk peneliti yang lain supaya lebih banyak mengembangkan media pembelajaran untuk siswa, khususnya pada sekolah dasar. Karena, pada tahapan pendidikan ini siswa lebih mudah dibentuk karakter dan keterampilan berpikir kritisnya. Kedua, untuk guru atau tenaga pendidik supaya lebih kreatif dalam menyampaikan materi pelajaran agar lebih mudah dipahami oleh siswa, salah satunya menggunakan media pop-up book. Terakhir peneliti meminta pihak sekolah dan dinas terkait untuk menyediakan dana pendidikan khusus terhadap pembuatan media pembelajaran yang menarik dan efektif pada jenjang sekolah dasar.

\section{DAFTAR PUSTAKA}

Aeni, N. (2018). Pendidikan Nilai Nasionalisme Dengan Media Pop Up Book Untuk Meningkatkan Berpikir Kritis Siswa Kelas V Sekolah Dasar. Jurnal Review Pendidikan Dasar: Jurnal Kajian Pendidikan Dan Hasil Penelitian, 4(3), 752-762.

Arip, M., \& Aswat, H. (2021). Media Pop Up Book Untuk Meningkatkan Hasil Belajar Siswa Pada Mata Pelajaran Ipa Di Sekolah Dasar. Edukatif: Jurnal Ilmu Pendidikan, 3(1), 261-268.

Azizah, M., Sulianto, J., \& Cintang, N. (2018). Analisis Keterampilan Berpikir Kritis Siswa Sekolah Dasar Pada Pembelajaran Matematika Kurikulum 2013. Jurnal Penelitian Pendidikan, 35(1), 61-70.

Dewanti, H., Toenlioe, A. J. E., \& Soepriyanto, Y. (2019). Pengembangan Media Pop-Up Book Untuk Pembelajaran Lingkungan Tempat Tinggalku Kelas Iv Sdn 1 Pakunden Kabupaten Ponorogo. Jurnal Kajian Teknologi Pendidikan, 1(3), 221-228.

Ennis, R. H. (2015). Critical Thinking And Subject Specificity: Clarification And Needed Research. Educational Researcher, 18(3), 4-10.

Fitri, N. A., \& Karlimah, K. (2018). Pengembangan Media Pop-Up Book Kubus Dan Balok Untuk Siswa Kelas V Sekolah Dasar. Pedadidaktika: Jurnal Ilmiah Pendidikan Guru Sekolah Dasar, 5(4), 226-239.

Kustandi, C., \& Darmawan, D. (2020). Pengembangan Media Pembelajaran: Konsep \& Aplikasi Pengembangan Media Pembelajaran Bagi Pendidik Di Sekolah Dan Masyrakat. Prenada Media.

Kustiawan, U. (2016). Pengembangan Media Pembelajaran Anak Usia Dini. Penerbit Gunung Samudera 
523 Pengembangan Media Pop-Up Book terhadap Keterampilan Berpikir Kritis pada Siswa Sekolah Dasar - Lailatus Suroiha, Galuh Kartika Dewi, Satrio Wibowo

DOI: https://doi.org/10.31004/edukatif.v4i1.1856

[Grup Penerbit Pt Book Mart Indonesia].

Lestari, D. A., \& Farhurohman, O. (2020). Pengaruh Media Pop-Up Book Terhadap Motivasi Belajar Dan Kemampuan Berpikir Kritis Pada Siswa Kelas Iv Min 1 Serang. Primary: Jurnal Keilmuan Dan Kependidikan Dasar, 12(2), 155-166.

Lismaya, L. (2019). Berpikir Kritis \& Pbl:(Problem Based Learning). Media Sahabat Cendekia.

Masithohsari, A., Fakhriyah, F., \& Ardianti, S. D. (2020). Model Student Team Achievement Divisions Berbantu Media Pop Up Book Dalam Meningkatkan Kemampuan Berpikir Kritis Siswa. Jrpd (Jurnal Riset Pendidikan Dasar), 3(2), 110-117.

Rachmantika, A. R., \& Wardono, W. (2019). Peran Kemampuan Berpikir Kritis Siswa Pada Pembelajaran Matematika Dengan Pemecahan Masalah. Prisma, Prosiding Seminar Nasional Matematika, 2, 439-443.

Rachmadtullah, R. (2015). Kemampuan Berpikir Kritis Dan Konsep Diri Dengan Hasil Belajar Pendidikan Kewarganegaraan Siswa Kelas V Sekolah Dasar. Jurnal Pendidikan Dasar, 6(2), 287-298.

Sholeh, M. (2019). Pengembangan Media Pop-Up Book Berbasis Budaya Lokal Keberagaman Budaya Bangsaku Siswa Kelas Iv Sekolah Dasar. Jurnal Gentala Pendidikan Dasar, 4(1), 138-150.

Sugiarti, L., \& Handayani, D. E. (2017). Pengembangan Media Pokari Pokabu (Pop-Up Dan Kartu Ajaib Pengelompokkan Tumbuhan) Untuk Siswa Kelas Iii Sd/Mi. Al Ibtida: Jurnal Pendidikan Guru Mi, 4(1), $109-118$.

Sudjana, N. (2020). Dasar-Dasar Proses Belajar Mengajar. Bandung: Pt Sinar Baru Algesindo.

Sugiyono. (2016). Metode Penelitian Kuantitatif Kualitatif Dan R\&D. Bandung: Cv. Alfabeta.

Sulistiani, E., \& Masrukan, M. (2017). Pentingnya Berpikir Kritis Dalam Pembelajaran Matematika Untuk Menghadapi Tantangan Mea. Prisma, Prosiding Seminar Nasional Matematika, 605-612.

Sylvia, N. I., \& Hariani, S. (2015). Pengaruh Penggunaan Media Pop-Up Book Terhadap Keterampilan Menulis Narasi Siswa Sekolah Dasar. Jurnal Pgsd Universitas Negeri Surabaya, 3(02), 1197-1205.

Umam, N. K., Bakhtiar, A. M., \& Iskandar, H. (2019). Pengembangan Pop Up Book Bahasa Indonesia Berbasis Budaya Slempitan. Trapsila: Jurnal Pendidikan Dasar, 1(02), 1-11. 